\title{
XXVI. Remarks on Iridina, a genus of fresh-water bivalve shells; with the specific characters of three species
}

\author{
William Swainson Esq. F.R.S. F.L.S.
}

To cite this article: William Swainson Esq. F.R.S. F.L.S. (1823) XXVI. Remarks on Iridina, a genus of fresh-water bivalve shells; with the specific characters of three species, Philosophical Magazine Series 1, 61:298, 112-113, DOI: 10.1080/14786442308644281

To link to this article: http://dx.doi.org/10.1080/14786442308644281

电 Published online: 27 Jul 2009.

Submit your article to this journal $₫$

Џll Article views: 2

Q View related articles $\sqsubset$ 
Such appears to me to be the most natural development of the confused and partly contradictory accounts, which the ancients have bequeathed to us, of their knowledge and acquisition of tin.

XXVI. Remarlss on Iridina, a Genus of Fresh-rvater Bivalve Shells; with the Specific Characters of three Species. By William Swainson, Esq. F.R.S. F.L.S. \&s.*

NEITHER Linnæus nor any of his followers appear to have been acquainted with the shell, on which Lamarck has founded the genus Iridina; a fresh-water bivalve of great rarity, and supposed to be a native of South America. Only one species being known to that celebrated naturalist, his acconnt of it is unaccompanied by any specific character; another has been figured by Mr. Sowerby, under the name of I. elongata, but without any definition. Having recently met with a third species, I now beg to offer such specific characters for all three, as may serve to distinguish them in the system; subjoining at the same time a modification of the generic characters as defined by Lamarck.

1. Iridina (Familia Naiadce).

'Testa æquivalvis, inæquilatera, transversa; umbonibus decorticatis. Cardo longus, linearis, pèr longitudinem tuberculosus; subcrenatus: tuberculis inæqualibus crebris; ligamentum externum, marginale.

Shell equivalve, the sides unequal, transverse; umbones decorticated. Hinge-plate long, linear, broken into obtuse, crenated, unequal, crowded tubercles. Ligament external and marginal.

Obs.-The animal of this genus is unknown; but, judging from the shell, its situation in the system will be intermediate between Unio and Anodon : the brilliancy of the pearly interior of the valves is highly beautiful.

Species.-1, Iridina striata.

I. testâ transversim oblongâ, anticè latâ, extremitate utrâque striis radiatis ornatâ ; margine basali sinuato.

Shell transversely oblong, anteriorly broad, with radiated striæ at each extremity; basal margin sinuated. Iridina exotica. Lam. Syst. vol. vi. p. 89. Ency. Meth. pl. 204. (bis.) f. 1. $a . b$.

This grand and excessively rare shell, I only know from the description of Lamarck, and the figure above quoted; neither am I aware that it exists in any collection in this coun-

* Communicated by the Author. 
try. Judging from the figure, the breadth of the shell is rather more than six inches; its length, from the umbones to the basal margin, two and a quarter; and at the anterior end two and a half: from the umbones diverge two sets of radiating strix crossing both the extremities; but whether these striæ are elevated or depressed is uncertain; the basal margin is sinuated, or gradually contracted, in the middle.

The specific name of exotica, given by Lamarck to this species, being applicable to all that are known, I have proposed that of striata as descriptive of its peculiar character.

2. Iridina elongata.

I. testâ lævi, transversim oblongâ, anticè latâ; margine basali integro; umbonibus subretusis.

Shell smooth, transversely oblong, anteriorly broad; basal margin entire; umbones subretuse.-I. elongata. Sowerby's Genera.

Not having myself examined this shell, $I$ can only judge of its characters from the figure given by Mr. Sowerby, and to which no description is subjoined. It appears perfectly smooth, of a greenish olive colour, and the umbones less prominent than the last : the basal margin also is not sinuated; and the size somewhat smaller. This shell is now in the possession of the Rev. Dr. Groodall.

3. Iridina ovata.

I. testâ lævi, transversim ovatâ ; umbonibus prominentibus, vix mediis.

Shell smooth, transversely oval; umbones prominent and nearly medial.

One perfect valve of this excessively rare shell has recently come to my hands, and is remarkably distinct from the two preceding. Its form is short and oval; the umbones very prominent, and nearly placed on the middle of the hinge margin. The colour dark-brown tinged with greenish, and entirely smooth.

There is one valve of a species belonging to this genus in the British Museum; it is polished, and the margin appears to have been cut; the name attached to it is Iridina exotica; that it is not the Iridina exotica of Lamarck, is too obvious to require argument. If it be a valve of any of the species here enumerated, it most probably is one belonging to the species last described; but, from its imperfect state, the question cannot positively be decided.

Vol. 61. No. 298. Feb. 1823. 